Supplementary Figure 6. Determinants of renin secretion in the model

\title{
Renin Secretion
}

Renin Synthesis $=$ MD Effect $\times$ Symp Effect $\times$ ANPEffect $\times$ Renal Mass $\% \times$ Base

Renin Mass = Renin Synthesis - Renin Secretion

Renin Secretion $=$ MD Effect $\times$ Symp Effect $\times$ ANPEffect $\times$ Renin Mass $\times K$

Base synthesis $=160 \mathrm{GU} / \mathrm{min}$

$K=0.00165$
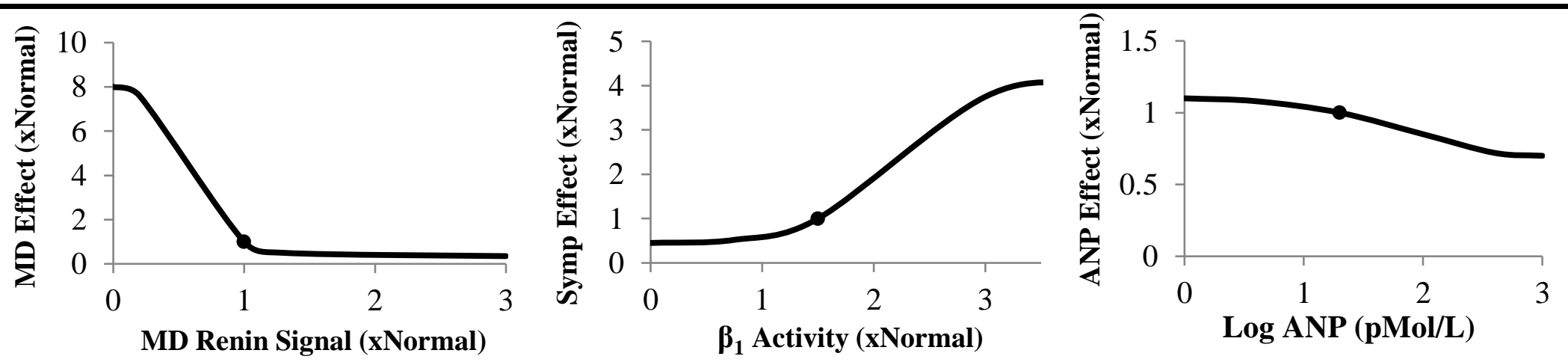

MD indicates macula densa; symp, sympathetic; and ANP, atrial natriuretic peptide. 